\title{
Diet digestibility and performance of dairy cows supplemented with live yeast
}

\author{
Luciene Lignani Bitencourt ${ }^{1}$; José Ricardo Martins Silva²; Bruno Menezes Lopes de Oliveira ${ }^{1}$; \\ Gilson Sebastião Dias Júnior ; Fernanda Lopes ${ }^{3}$; Sancho Siécola Júnior ${ }^{1}$; Ozana de Fátima \\ Zacaroni $^{1}$; Marcos Neves Pereira ${ }^{1 *}$ \\ ${ }^{1}$ UFLA - Depto. de Zootecnia, C.P. 3037 - 37200-000 - Lavras, MG - Brasil. \\ ${ }^{2}$ Instituto Federal do Norte de Minas - Fazenda São Geraldo s/n, km 6 - 39480-000 - Januária, MG - Brasil. \\ ${ }^{3}$ University of Wisconsin - Dept. of Dairy Science, 1675 Observatory Drive, Madison, 53706-1205 - WI, USA. \\ *Corresponding author <mpereira@dzo.ufla.br>
}

\begin{abstract}
Dietary yeast supplementation may improve the digestive efficiency of ruminants, but responses depend on the yeast strain and the diet composition. Corn silage and citrus pulp are usual carbohydrate sources for dairy cows in southeast Brazil. This study evaluated the supplementation of dairy cows fedding on corn silagecitrus pulp-based diets with Saccharomyces cerevisiae CNCM I-1077 (Lallemand SAS, Toulouse, France). Twenty multiparous, midlactation Holstein cows were assigned to two treatments in crossover design. Treatments were: live yeast on oyster meal capable of supplying a daily minimum of $1 \times 10^{10} \mathrm{CFU}$ per cow or oyster meal top-dressed at $10 \mathrm{~g}$ to the morning meal. Diet contained (\% of dry matter): $16.8 \%$ crude protein, $30.9 \%$ neutral detergent fiber, $43.9 \%$ corn silage, $2 \%$ tifton hay, $14.4 \%$ steam flaked corn, $16.9 \%$ citrus pulp and $21.7 \%$ soybean meal. Yeast supplementation increased daily yields of milk (29.4 vs. $28.5 \mathrm{~kg}, p=0.11)$, protein (0.939 vs. $0.908 \mathrm{~kg}, p=$ $0.05)$, and lactose (1.294 vs. $1.241 \mathrm{~kg}, p=0.06)$, but did not affect milk fat contents $(p=0.59)$. Daily dry matter intake was 21.4 with yeast and $20.7 \mathrm{~kg}$ for the control $(p=0.11)$. Total tract apparent digestibility of the neutral detergent fiber was $48.1 \%$ with yeast and $43.2 \%$ for the control $(p=0.08)$. There was a trend for increased intake of digestible organic matter with yeast supplementation $(p=0.07)$. The positive milk protein yield response to yeast supplementation may have resulted from the increased fiber digestibility, but the response mechanism could not be elucidated.
\end{abstract}

Key words: Saccharomyces cerevisiae, citrus pulp, probiotic

\section{Digestibilidade da dieta e desempenho de vacas leiteiras suplementadas com levedura viva}

\begin{abstract}
RESUMO: A suplementação com levedura pode melhorar a eficiência digestiva de ruminantes. Entretanto, a resposta depende da cepa de levedura e da composição da dieta. Silagem de milho e polpa cítrica são fontes frequentes de carboidratos para vacas leiteiras no Sudeste do Brasil. Avaliou-se a suplementação de vacas leiteiras alimentadas com dieta baseada em silagem de milho e polpa cítrica com Saccharomyces cerevisiae cepa CNCM I1077 (Lallemand SAS, Toulouse, França). Vinte vacas Holandesas multíparas em meio de lactação foram alocadas a uma seqüência de dois tratamentos em delineamento de reversão simples. Os tratamentos foram: $10 \mathrm{~g}$ de levedura viva em farinha de ostra para fornecer um mínimo diário de $1 \times 10^{10}$ ufc por vaca ou farinha de ostra fornecidos sobre a refeição matinal. A dieta continha (\% da matéria seca): $16,8 \%$ de proteína bruta, 30,9\% de fibra em detergente neutro, $43,9 \%$ de silagem de milho, $2 \%$ de feno de tifton, $14,4 \%$ de milho floculado, $16,9 \%$ de polpa cítrica e $21,7 \%$ de farelo de soja. A suplementação com levedura aumentou as produções diárias de leite (29,4 vs. $28,5 \mathrm{~kg}, p=0,11)$, proteína $(0,939$ vs. $0,908 \mathrm{~kg}, p=0,05)$ e lactose $(1,264$ vs. $1,241 \mathrm{~kg}, p=0,06)$, e não teve efeito sobre a gordura do leite $(p=0,53)$. O consumo diário de matéria seca foi $21,4 \mathrm{~kg}$ com levedura e 20,7 no controle $(p=0,11)$. A digestibilidade aparente da fibra em detergente neutro no trato digestivo total foi $48,1 \% \mathrm{com}$ levedura e $43,2 \%$ para o controle $(p=0,08)$. Houve tendência de aumento no consumo de matéria orgânica digestível com a suplementação de levedura $(p=0,07)$. A resposta positiva em secreção de proteína do leite à suplementação com levedura parece ter sido resultado do aumento na digestibilidade da fibra, mas o mecanismo para a resposta não pôde ser elucidado.

Palavras-chave: Saccharomyces cerevisiae, polpa cítrica, probiótico
\end{abstract}

\section{Introduction}

Dietary supplementation of microbial additives, such as live yeast, may improve digestive efficiency in ruminants (Wallace, 1994). These microbial performance promoters have been favored over chemicals because of the current trend of consumers for choosing natural and organic alternatives. Yeasts are naturally found in the rumen, but the rumen temperature does not promote their growth, optimal at $25^{\circ} \mathrm{C}$ (Lund, 1974), therefore using yeasts as feed additives require continuous daily supplementation. 
Animals respond to dietary yeast supplements depending on dosage and type of microorganism, composition of basal diet, and feed management practices (Newbold et al., 1995). Commercially available yeast products vary according to species and strain, number of live cells, and microorganisms' growth medium (Erasmus et al., 1992). Therefore, not all types may cause the same effect on a given dietary-induced rumen environment (Callaway and Martin, 1997), and thus the effectiveness of industrially produced strains on rumen fermentation and animal performance needs to be tested.

The primary mechanism by which yeasts affect animal performance seems to be related to the ruminal function (Chaucheyras-Durand et al.; 2008; Dawson et al. 1990). Supplementation of dairy cows with live yeast strains may improve dry matter intake (Erasmus et al., 1992; Wohlt et al., 1991) and milk yield (Erasmus et al., 1992; Piva et al., 1993; Williams et al., 1991), and overall performance response of dairy cows (Sniffen et al., 2007).

Researchers have demonstrated the potential of Saccharomyces cerevisiae strain CNCM I-1077 for stimulating microbial populations (Michalet-Doreau et al., 1997), specially the growth and activity of fiber-degrading bacteria (Chaucheyras-Durand and Fonty, 2001; Guedes et al., 2008; Mosoni et al., 2007). The aptitude of live yeast supplements of stabilizing rumen $\mathrm{pH}$, strengthening the reducing power of the rumen fluid, may improve total tract dietary fiber digestibility (Marden et al., 2008).

Corn silage and citrus pulp are usually used as dietary carbohydrate sources for lactating cows in Southeast Brazil (Salvador et al., 2008a). This high energy, low protein by-product of the citrus juice industry usually has lower cost than corn grain, turning substitution of corn by citrus pulp a viable economic alternative (Salvador et al., 2008b). However, the possibility of obtaining favorable cow performance response to live yeast supplementation on such diets needs to be established. This study aimed at evaluating the effect of dietary supplementation of Saccharomyces cerevisiae CNCM I-1077 on performance and digestive efficiency of dairy cows fed a diet based on corn silage and high inclusion of pelleted citrus pulp, partially substituting corn.

\section{Material and Methods}

Twenty, multiparous Holstein cows, $(143 \pm 48.8$ days in lactation) were block-paired based on milk yield. One animal was randomly assigned to one of the two treatment sequences within each block in a crossover design with 28-day periods. Half of the animals received each treatment on experimental periods one and two. Treatments were $1 \mathrm{~g}$ of live yeast (Saccharomyces cerevisiae strain CNCM I-1077; Lallemand SAS, Toulouse, France) diluted in $9 \mathrm{~g}$ of oyster meal or $10 \mathrm{~g}$ of oyster meal to yield a daily minimal intake of $1 \times 10^{10} \mathrm{CFU}$ of yeast per cow. Yeast concentration was determined by aerobic counts of viable yeast cells on Yeast Extract-Peptone-Dextrose agar with $0.1 \%$ chloramphenicol. There were $1.47 \times 10^{9}$ viable cells per $\mathrm{g}$ of the diluted yeast product (CFU count). A two-week washout period was observed between experimental periods, during which animals received the non-supplemented treatment. Responses to treatments were evaluated along the fourth week of each experimental period.

Cows were housed in total confinement in sand bedded tie stalls and individually fed twice a day with a mixed ration offered to allow a minimum of $15 \%$ of the offered as the daily ort per cow (Table 1). Treatments were top-dressed to the feed offered to each cow in the morning.

Between the $23^{\text {rd }}$ and $27^{\text {th }}$ day of each period, samples of corn silage, concentrate ingredient and orts of each cow were taken daily and frozen; composite samples for each period were taken based on identical amounts of fresh matter. Samples were dried at $55^{\circ} \mathrm{C}$ in a forced air oven for $72 \mathrm{~h}$ and ground through a $1-\mathrm{mm}$ mesh (Wiley mill, Thomas Scientific, Philadelphia, USA); subsamples were dried at $100^{\circ} \mathrm{C}$ for $24 \mathrm{~h}$ for dry matter content determination. Crude protein contents were determined in a Micro Kjeldahl steamer distiller (AOAC, 1975); ether extract contents were determined according to the AOAC (1990); ash contents were determined by incinerating samples at $550^{\circ} \mathrm{C}$ for $8 \mathrm{~h}$; the neutral detergent fiber (NDF) contents were determined using an ANKON $^{\circledR}$ Fiber Analyzer (ANKOM Technology Corporation, Fairport, USA) with the addition of alpha-amylase and sodium sulfite.

Cows were milked twice a day. Samples from six consecutive milkings were taken on days 23, 24 and 25 of each period for protein, fat, lactose, and milk urea nitrogen (MUN) contents to be determined. Milk components were measured

Table 1 - Ingredient composition of the diets and nutrient composition of the consumed diet.

\begin{tabular}{lr}
\hline \multicolumn{1}{c}{ Ingredient } & \% of dry matter \\
\hline \multicolumn{1}{c}{ Corn silage } & 43.9 \\
Tifton hay & 2.0 \\
\hline Soybean meal & 21.7 \\
Citrus pulp & 16.9 \\
\hline Steam-flaked corn & 14.4 \\
Limestone & 0.4 \\
\hline NaCl & 0.3 \\
Mineral vitamin mix ${ }^{1}$ & 0.3 \\
\hline \multicolumn{1}{c}{ Nutrient } & \\
\hline Crude protein & 16.8 \\
\hline Neutral detergent fiber & 30.9 \\
Corn silage neutral detergent fiber & 20.8 \\
\hline Tifton neutral detergent fiber & 1.5 \\
\hline Ether extract & 5.4 \\
\hline Ash & 5.9 \\
\hline Non-fiber carbohydrates & \\
\hline
\end{tabular}

${ }^{1}$ Mineral vitamin mix: $18.5 \%$ of $\mathrm{Ca} ; 15 \%$ of $\mathrm{P} ; 3.0 \%$ of $\mathrm{Mg} ; 3.0 \%$ of S; $240 \mathrm{mg} \mathrm{kg}^{-1}$ of $\mathrm{Co} ; 3000 \mathrm{mg} \mathrm{kg}^{-1}$ of Cu; $8000 \mathrm{mg} \mathrm{kg}^{-1}$ of Mn; $12000 \mathrm{mg} \mathrm{kg}^{-1}$ of $\mathrm{Zn} ; 90 \mathrm{mg} \mathrm{kg}^{-1}$ of Se; $180 \mathrm{mg} \mathrm{kg}^{-1}$ of I; 1.000 .000 IU kg vitamin A; $250.000 \mathrm{IU} \mathrm{kg}^{-1}$ vitamin $\mathrm{D}$; $6.250 \mathrm{IU} \mathrm{kg}^{-1}$ vitamin E. ${ }^{2}$ Non-fiber carbohydrates $=100-($ crude protein + neutral detergent fiber + ether extract + ash) 
by infrared analysis and urea nitrogen was determined by an enzymatic and spectrophotometric trans-reflectance method. Daily yields of milk and solids between days 23 and 25 were used to compare treatments. The daily secretion of milk energy was calculated as $[(0.0929 \times \%$ fat $)+(0.0547 \times \%$ protein $)+(0.0395 \times \%$ lactose $)] \times \mathrm{kg}$ of milk $(\mathrm{NRC}, 2001)$.

Body weight and body condition score of each cow were determined on the 27 th day of each period. Body condition of cows was scored using the one (1) to five (5) system (thin to fat) of Wildman et al. (1982). The same three independent evaluators scored each cow, and the mean values - 649 $\mathrm{kg}$ for body weight and 3.37 for body condition score - were calculated for each experimental period.

Blood was drawn from the coccygeal vein of individual cows on the 22nd day of each period to determine plasma urea nitrogen (PUN) contents. Samples were obtained immediately before the morning meal (PUN B) and two hours after feeding (PUN 2). Blood was collected in tubes added of $0.2 \mathrm{~mL}$ of glistab as and stored under refrigeration. Blood samples were centrifuged at $1,000 \times g$ for $15 \mathrm{~min}$, and the obtained plasma was frozen at $-20^{\circ} \mathrm{C}$ until analysis of urea using a commercial kit (Labtest Diagnóstica S.A.; Lagoa Santa, MG, Brazil; Cat\# 27).

Total tract apparent digestibility of dry matter, organic matter, NDF and non-NDF organic matter were determined by total fecal collection. The total of feces excreted from each cow was manually collected in buckets held by observers, one for each pair of cows, during three continuous collection periods of eight hours, on days 25 to 27 of each period. To obtain a representative sample of $24 \mathrm{~h}$ without disturbing feed intake and milk yield, sampling started $8 \mathrm{~h}$ later in relation to the collection done on the previous day. Uniform fecal samples from each cow were continuously frozen along each collection day to yield a composite sample at the end of each period. Fecal composite samples were oven dried at $55^{\circ} \mathrm{C}$ for $72 \mathrm{~h}$ and the $100^{\circ} \mathrm{C}$ dry matter, NDF and ash contents were determined as previously described.

Daily digestible organic matter intake (DOMI) was calculated by multiplying the intake of organic matter measured on days 23 through 27 by the organic matter digestibility measured on days 25 through 27 . Feed efficiency was determined as the ratio between milk yield and dry matter intake. The efficiency of energy usage was defined by the ratio between the daily secretion of milk energy and the daily dry matter intake or the DOMI.

On the $27^{\text {th }}$ day of each period, samples of rumen fluid were taken with a flexible orogastric probe with the help of a vacuum suction pump connected to a Kitassato vessel (Rosenberger, 1993). To obtain a sample theoretically representative of the rumen fluid around the moment of lowest $\mathrm{pH}$-highest volatile fatty acid (VFA) concentration, samples were taken at $13 \mathrm{~h} \pm 37 \mathrm{~min}$ after the morning feeding(Salvador et al., 2008a). Animals were randomly sampled within block. The $\mathrm{pH}$ was measured immediately after sampling. The ruminal fluid collected from each cow was parted in two samples. One sample had its fermentation suppressed by instantaneous freezing in liquid nitrogen at $-196^{\circ} \mathrm{C}$ and was kept frozen until later analysis of VFA by gas-liquid chromatography (CP 3800 Gas Chromatography Varian, Varian Chromatography Systems, California, USA). The other sample was homogenized and diluted 1:2 with formaldehyde for determining the relative counting of ciliate protozoa (Dehority, 1984). A $1.0-\mathrm{mL}$ sample of ruminal fluid in formaldehyde was allocated to Neubauer chambers in $0.1 \mathrm{~mm}$ depth for optic microscope enumeration (Warner, 1962). The average of two microscopic field counts was estimated as the number of organisms per $\mathrm{mL}$.

Chewing activity was evaluated on day 28 by visual observation of the buccal activity of each animal, every five minutes, continuously for $24 \mathrm{~h}$. Buccal activities evaluated were water intake, ingestion, rumination, and idle. Chewing time, in minutes per day, was defined by the sum of the ingestion and rumination times. Chewing, ingestion, and rumination times per unit of dry matter intake were calculated considering the intake of the day in which chewing activity was evaluated.

The concentration of purine derivatives in urine was used to estimate relative differences in the production of microbial protein in the rumen. Urine samples were collected at the beginning and at the end of each of the three 8-h periods of fecal collection on days 25 through 27 . Ten milliliters of $10 \%$ sulphuric acid was added to $100 \mathrm{~mL}$ of urine; samples were kept at $4^{\circ} \mathrm{C}$. A composite sample from each cow was formed at the end of each period. Composite samples were diluted 1 to 3 with distillated water and frozen at $-20^{\circ} \mathrm{C}$ for analysis of allantoin and creatinine. Allantoin was analyzed according to Chen and Gomes (1995) whereas creatinine was analyzed with a commercial kit (Labtest Diagnóstica S.A., Lagoa Santa, Minas Gerais. Cat. \# 35-100).

Data were analyzed using the GLM procedure of SAS (1998), under model: $\mathrm{Y}_{\mathrm{i} \mathrm{j} k \mathrm{l}}=\mu+\mathrm{B}_{\mathrm{i}}+\mathrm{V}_{\mathrm{j}(\mathrm{i})}+\mathrm{P}_{\mathrm{k}}+\mathrm{T}_{1}+\mathrm{e}_{\mathrm{ijk} \mathrm{k},}$, where: $\mu=$ global mean; $\mathrm{B}_{\mathrm{i}}=$ block effect $(\mathrm{i}=1$ to 10$)$; $\mathrm{V}_{\mathrm{i}(\mathrm{i})}$ $=\operatorname{cow}$ within block $(\mathrm{j}=1$ to 20$) ; \mathrm{P}_{\mathrm{k}}=$ period effect $(\mathrm{k}=1$ or 2$) ; \mathrm{T}_{1}=$ treatment effect $\left(1=\right.$ Yeast or Control); and $\mathrm{e}_{\mathrm{ijkl}}=$ experimental error, assumed independently and identically distributed in a normal distribution with average zero and variance $\sigma^{2}$. Frequencies of rumen $\mathrm{pH}$ values above or below 6.2 were evaluated using the Chi-Square statistic with the FREQ procedure of SAS (1998). Significance was defined at $p \leq 0.05$ and trends at $p \leq 0.11$.

\section{Results and Discussion}

The Saccharomyces cerevisiae strain CNCM I-1077 induced a positive response in daily protein yield of mid-lactation cows consuming a corn silage-citrus pulp based diet (Table 2). Positive trends were recorded for milk and lactose yields; and for increased feed intake (Table 2) and fiber digestibility (Table 3) with increasing dietary yeast supplementation, which led to a tendency for greater DOMI (Table 2). Positive response in feed intake and milk production to live yeast supplementation, associated with improved digestibility of nutrients, has also been observed by Erasmus et al. (1992), Williams et al. (1991), and Wohlt et al. (1998). In a review of 14 experiments, representing 193 cow observations, the average response in milk yield to yeast supplemen- 
tation was 1.45 L (Sniffen et al., 2007); in studies measuring the daily dry matter intake, the average increase was $0.53 \mathrm{~kg}$ (Sniffen et al., 2007).

Although the dietary contents of forage and fiber complied with the minimal levels of fibrous carbohydrates required by lactating cows (NRC, 2001), the corn used in the concentrate underwent industrial thermal processing which increased starch digestibility (Theurer et al., 1999). Additionally, the diet was not supplemented with buffers, alkalinizes, or other manipulators of ruminal fermentation (Table 1). Diet also had high contents of corn silage from a floury endosperm hybrid and citrus pulp, which are quickly fermented in the rumen (Correa et al., 2002; Miron et al., 2001). This dietary profile may have contributed to the responses registered to yeast supplementation. Actually, diets capable of increasing rumen environment acidity may favor the response potential to yeast supplementation (Williams et al., 1991; Longuski et al. (2009).
The trend for increased dry matter and NDF digestibility with increasing dietary yeast supplementation (Table 3) suggests that the increase in DOMI may have been mediated by the gain in fiber digestion. Longuski et al. (2009) reported a negative effect of yeast on the rumination activity of dairy cows, which can suggest that fiber digestibility responds positively to the yeast supplementation. However, similar phenomenon was not recorded in the present study (Table 3). The beneficial effect of yeast on the digestibility of fiber has been shown in vivo (Erasmus et al., 1992; Guedes et al., 2008; Marden et al., 2008; Wiedmeier et al., 1987; Wohlt et al., 1998; and several mechanisms have been suggested to account for such a response (Wallace, 1994). An increase in the total number of bacteria in the rumen, mainly the fibrolytic bacteria, appears to be the main mechanism by which yeast supplementation improves digestion of fiber (Chaucheyras-Durand and Fonty, 2001; Mosoni et al., 2007; Wallace and Newbold, 2007).

Table 2 - Performance of dairy cows supplemented (Yeast) or not (Control) with live yeast.

\begin{tabular}{|c|c|c|c|c|}
\hline & Yeast & Control & SEM $^{1}$ & $P$ \\
\hline Dry matter intake (kg per day) & 21.4 & 20.7 & 0.32 & 0.11 \\
\hline Organic matter intake (kg per day) & 20.2 & 19.4 & 0.30 & 0.10 \\
\hline Digestible organic matter intake (kg per day) & 14.9 & 14.1 & 0.32 & 0.07 \\
\hline Milk yield (kg per day) & 29.4 & 28.5 & 0.36 & 0.11 \\
\hline Fat yield (kg per day) & 0.931 & 0.920 & 0.0148 & 0.59 \\
\hline Protein yield (kg per day) & 0.939 & 0.908 & 0.0114 & 0.05 \\
\hline Lactose yield (kg perday) & 1.294 & 1.241 & 0.0185 & 0.06 \\
\hline Fat content $(\%)$ & 3.23 & 3.31 & 0.044 & 0.27 \\
\hline Protein content $(\%)$ & 3.24 & 3.24 & 0.010 & 0.64 \\
\hline Lactose content $(\%)$ & 4.43 & 4.40 & 0.022 & 0.39 \\
\hline Milk urea nitrogen $\left(\mathrm{mg} \mathrm{dL}^{-1}\right)$ & 14.6 & 14.3 & 0.25 & 0.44 \\
\hline Milk energy (Mcal per day) & 19.0 & 18.7 & 0.24 & 0.29 \\
\hline Milk yield/dry matter intake & 1.37 & 1.39 & 0.022 & 0.60 \\
\hline Milk energy/dry matter intake $\left(\mathrm{Mcal} \mathrm{kg}^{-1}\right)$ & 0.89 & 0.91 & 0.016 & 0.32 \\
\hline Milk energy/digestible OM intake (Mcal kg $\left.{ }^{-1}\right)$ & 1.28 & 1.35 & 0.036 & 0.16 \\
\hline
\end{tabular}

${ }^{1} \mathrm{SEM}=$ Standard error of the means.

Table 3 - Total tract apparent digestibility and chewing activity of dairy cows supplemented (Yeast) or not (Control) with live yeast.

\begin{tabular}{|c|c|c|c|c|}
\hline & Yeast & Control & $\mathrm{SEM}^{1}$ & $P$ \\
\hline Dry matter digestibility ( $\%$ of intake) & 71.9 & 69.9 & 0.91 & 0.12 \\
\hline Organic matter digestibility ( $\%$ of intake) & 74.1 & 72.4 & 0.88 & 0.20 \\
\hline Neutral detergent fiber digestibility ( $\%$ of intake) & 48.1 & 43.2 & 1.86 & 0.08 \\
\hline Non-NDF organic matter digestibility ( $\%$ of intake) & 86.7 & 86.7 & 0.68 & 0.95 \\
\hline Rumination (min per day) & 414 & 417 & 12.0 & 0.86 \\
\hline Ingestion (min per day) & 263 & 253 & 6.8 & 0.31 \\
\hline Rumination+Ingestion (min per day) & 678 & 671 & 15.5 & 0.75 \\
\hline Rumination (min per kg of dry matter intake per day) & 19.6 & 21.2 & 0.90 & 0.22 \\
\hline Ingestion (min per $\mathrm{kg}$ of dry matter intake per day) & 12.4 & 12.8 & 0.53 & 0.59 \\
\hline Rumination+Ingestion (min per kg of dry matter intake per day) & 32.0 & 34.0 & 1.34 & 0.30 \\
\hline
\end{tabular}

${ }^{1} \mathrm{SEM}=$ Standard error of the means. 
The relative synthesis of microbial protein, estimated by the allantoin to creatinine ratio in urine, did not differ among treatments (Table 4). Microbial growth could be stimulated by dietary yeast (Harrison et al., 1988; Newbold et al., 1995), which in turn could increase the flow of protein into the duodenum (Erasmus et al., 1992). However, the increased daily milk protein secretion with increasing yeast supplementation could not be explained by this mechanism.

Dietary yeast may promote microbial population growth in the rumen by increasing the $\mathrm{pH}$ (Nisbet and Martin, 1991; Chaucheyras et al., 1996; Marden et al., 2008). Supplementing lactating cows with CNCM I-1077 S. cerevisiae strain increases the mean $\mathrm{pH}$ in the rumen and reduces the daily time of pH below 5.6 and 6.0 (Bach et al., 2007). However, rumen $\mathrm{pH}$ measured $13 \mathrm{~h}$ after the first meal of the day was not increased when animals were supplemented with yeast (Table 4). The frequency of rumen $\mathrm{pH}$ below 6.2 was $20 \%$ in both treatments ( $p=1.0$ for Chi-Square). Samples obtained in our study were from ruminal fluid collected only at a specific point in time, which may have decreased the chance of finding treatment differences, as compared to other studies in which fluid has been collected in rumen-cannulated animals throughout the day, or in animals equipped with indwelling probes allowing monitoring of rumen $\mathrm{pH}$ variations during long periods of time (Bach et al., 2007; Erasmus et al., 1992). However, Mosoni et al. (2007) demonstrated that the positive effect of live yeast on the number of rumen fibrolytic bacteria may not be related to a simultaneous response in rumen $\mathrm{pH}$.

Brossard et al. (2004) suggest that the stabilizing effect of Saccharomyces cerevisiae upon rumen $\mathrm{pH}$ could be mediated by the stimulation of ruminal protozoa, capable of engulfing starch granules, which would thus compete with amylolytic bacteria for substrate and could induce slower degradation of starch in the rumen (Bonhomme, 1990). Brossard et al. (2004) detected an increase in protozoa popu- lation and in ruminal $\mathrm{pH}$ in sheep fed the same yeast strain used in this study. However, a treatment effect on rumen protozoa concentration could not be detected (Table 4). The mechanism by which the yeast induced the increase in fiber digestion could not be clarified.

Dietary yeast supplementation did not affect the efficiency of conversion of ingested dry matter into milk or on the conversion of DOMI into milk energy (Table 2). The use of yeast to manipulate the energetic efficiency of ruminants could not be established in this study. Chaucheyras et al. (1995) proposed that yeast could stimulate the hydrogenotrophic acetogenic bacteria found in the rumen, reducing the energy lost as methane, without, however, decreasing the acetate to propionate ratio, as known for ionophores (Schelling, 1984).

Schingoethe et al. (2004) reported that the supplementation of lactating cows' diets with a dead yeast product increased the efficiency of converting ingested dry matter into milk energy, similarly to the stimulus observed in acetogenic metabolism when autoclaved yeast was added to ruminal fluid in vitro (Chaucheyras et al., 1995). This particular mechanism would not necessarily require supplementation with viable cells (Newbold et al., 1996; Nisbet and Martin, 1991), but may require a greater amount of supplemental yeast in comparison to the amount used in this study (Nisbet and Martin, 1991).

Strains of Saccharomyces cerevisiae may differ in their ability to promote changes to ruminal fermentation (Newbold et al., 1995). In this study, no effect on ruminal fermentation profile was detected with strain CNCM I-1077, when evaluated considering the acetate to propionate ratio (Table 4). This finding agrees with that observed by Doreau and Jouany (1998), when working with the same strain and dosages of this study.

The reported effects of Saccharomyces cerevisiae on concentration of VFA in the rumen vary among authors

Table 4 - Urinary allantoin to creatinine ratio, rumen fermentation profile, and plasma urea nitrogen before feeding (PUN B) and $2 \mathrm{~h}$ after feeding (PUN 2) of dairy cows supplemented (Yeast) or not (Control) with live yeast.

\begin{tabular}{|c|c|c|c|c|}
\hline & Yeast & Control & SEM $^{1}$ & $P$ \\
\hline Allantoin/Creatinine & 6.32 & 5.05 & 1.035 & 0.40 \\
\hline Acetate $(\mathrm{mM})$ & 86.3 & 89.5 & 2.89 & 0.44 \\
\hline Propionate (mM) & 28.7 & 29.4 & 0.71 & 0.51 \\
\hline Butyrate $(\mathrm{mM})$ & 14.5 & 15.8 & 0.77 & 0.26 \\
\hline Total VFA $(\mathrm{mM})^{2}$ & 129.5 & 134.7 & 4.03 & 0.38 \\
\hline Acetate $(\%$ of total VFA) & 66.4 & 66.5 & 0.57 & 0.94 \\
\hline Propionate ( $\%$ of total VFA) & 22.3 & 21.8 & 0.38 & 0.36 \\
\hline Butyrate ( $\%$ of total VFA) & 11.2 & 11.8 & 0.33 & 0.36 \\
\hline Acetate/Propionate & 2.99 & 3.06 & 0.073 & 0.54 \\
\hline Protozoa $\left(\mathrm{x} 10^{4}\right.$ organisms $\left.\mathrm{mL}^{-1}\right)$ & 11.1 & 12.1 & 1.48 & 0.62 \\
\hline Rumen $\mathrm{pH}$ & 6.50 & 6.43 & 0.052 & 0.35 \\
\hline PUN B (mg dL $\left.{ }^{-1}\right)$ & 15.4 & 14.5 & 1.40 & 0.66 \\
\hline PUN $2\left(\mathrm{mg} \mathrm{dL} \mathrm{dL}^{-1}\right)$ & 17.7 & 18.1 & 2.06 & 0.91 \\
\hline
\end{tabular}

${ }^{1} \mathrm{SEM}=$ Standard error of the means; ${ }^{2}$ Total VFA $=$ Total volatile fatty acids $=$ Acetate + Propionate + Butyrate. 
(Erasmus et al., 1992; Erasmus et al., 2005; Doreau and Jouany, 1998; Piva et al., 1993; Wiedmeier et al., 1987; Williams et al., 1991). The potentialy positive effect of yeast on the ruminal acetogenesis from hydrogen (Chaucheyras et al., 1995) should increase the acetate to propionate ratio, a phenomenon which should also be expected as a result of increased activity of fibrolytic microorganisms, supposedly related to the greater fiber digestibility in yeast-supplemented diets (Wiedmeier et al., 1987; Wohlt et al., 1998). It seems appropriate to evaluate the frequency in which dietary yeast supplementation would induce an increase in the ratio of acetate to propionate, without causing an increase in methane excretion. However, many researchers found a decrease in the ratio of acetic to propionic acids when ruminants' diets are supplemented with yeast (Erasmus et al., 1992; Erasmus et al., 2005; Marden et al., 2008; Williams et al., 1991), probably as a result of stimulation of bacteria which can convert ruminal lactate into propionate by dietary yeast.

An effect of the yeast-supplemented diet on nitrogen metabolism could not be demonstrated, as showed by the similar concentrations of MUN (Table 2) and PUN (Table 4) across treatments. The proposed mechanism for a decrease in rumen ammonia concentration induced by yeast is related to the increased microbial growth and bacterial assimilation of nitrogen (Harrison et al., 1988). Alternatively, another explanation would be the decrease of certain bacterial peptidase activities due to the presence of yeast in the ruminal fluid (Chaucheyras-Durand et al., 2005; Putnam et al., 1997).

\section{Conclusions}

Supplementation of lactating cows with viable cells of Saccharomyces cerevisiae CNCM I-1077 increased the daily yield of protein and lactose in mid-lactation dairy cows fed a diet based on corn silage and high content of pelleted citrus pulp. The positive performance response of supplemented animals was most likely dictated by improved digestibility of fiber in the total digestive tract, although identification of the mechanisms responsible for the gain in fiber digestibility could not be clearly determined.

\section{Acknowledgements}

To Ourofino Saúde Animal and Lallemand SAS for the financial support.

\section{References}

Association of Official Analytical Chemists [AOAC]. 1975. Official Methods of Analysis. 12ed. AOAC, Washington, DC, USA.

Association of Official Analytical Chemists [AOAC]. 1990. Official Methods of Analysis. 15ed. AOAC, Arlington, VA, USA.

Bach, A.; Iglesias, C.; Devant, M. 2007. Daily rumen pH pattern of loosehoused dairy cattle as affected by feeding pattern and live yeast supplementation. Animal Feed Science Technology 136: 146-153.

Bonhomme, A. 1990. Rumen ciliates: their metabolism and relationships with bacteria and their hosts. Animal Feed Science Technology 30: 203-206.

Brossard, L.; Martin, C.; Chaucheyras, D.F. 2004. Protozoa involved in butyric rather than lactic fermentative pattern during latent acidosis in sheep. Reproduction, Nutrition, Development 44: 44-47.
Callaway, E.S.; Martin, S.A. 1997. Effects of Saccharomyces cerevisiae culture on ruminal bacteria that utilize lactate and digest cellulose. Journal of Dairy Science 80: 2035-2044.

Chaucheyras, F. ; Fonty, G. ; Bertin, G. ; Gouet, P. 1995. In vitro $\mathrm{H}_{2}$ utilization by a ruminal acetogenic bacterium cultivated alone or in association with an archae methanogen is stimulated by a probiotic strain of Saccharomyces cerevisiae. Applied Environmental Microbiology 61: 3466-3467.

Chaucheyras, F. ; Fonty, G. ; Bertin, G. ; Salmon, J.M. ; Gouet, P. 1996. Effects of a strain of Saccharomyces cerevisiae (Levucell SC), a microbial additive for ruminants, on lactate metabolism in vitro. Canadian Journal of Microbiology 42: 927-933.

Chaucheyras-Durand, F.; Fonty, G. 2001. Establishment of cellulolytic bacteria and development of fermentative activities in the rumen of gnotobiotically-reared lambs receiving the microbial additive Saccharomyces cerevisiae CNCM I-1077. Reproduction Nutrition Development 41: 57-68.

Chaucheyras-Durand, F.; Masseglia, S.; Fonty, G. 2005. Effect of microbial feed additive Saccharomyces cerevisiae CNCM I-1077 on protein and peptide degrading activities of rumen bacteria grown in vitro. Current Microbiology 50: 96-101.

Chaucheyras-Durand, F.; Walker, N.D.; Bach, A. 2008. Effects of active dry yeasts on the rumen microbial ecosystem: past, present and future. Animal Feed Science and Technology 145: 5-26.

Chen, X.B.; Gomes, J. 1995. Estimation of microbial protein supply to sheep and cattle based on urinary excretion of purine derivatives: an overview of the technical details. Rowett Research Institute, Bucksburn, Aberdeen, UK. 22p.

Correa, C.E.; Shaver, R.D.; Pereira, M.N.; Lauer, J.G.; Kohn, K. 2002. Relationship between corn vitreousness and ruminal in situ starch degradability. Journal of Dairy Science 85: 3008-3012.

Dawson, K.A.; Newman, K.E.; Boling, J.A. 1990. Effects of microbial supplements containing yeast and lactobacilli on roughage-fed ruminal microbial activities. Journal of Animal Science 68: 3392-3398.

Dehority, B. 1984. Evaluating of subsampling and fixation procedures used for counting rumen protozoa. Applied Environmental Microbiology 48:182-185.

Doreau, M.; Jouany, J.P. 1998. Effect of a Saccharomyces cerevisiae culture on nutrient digestion in lactating dairy cows. Journal of Dairy Science 81: 3214-3221.

Erasmus, L.J.; Botha, P.M.; Kistner, A. 1992. Effect of yeast culture supplement on production, rumen fermentation, and duodenal nitrogen flow in dairy cows. Journal of Dairy Science 75: 3056-3065.

Erasmus, L.J.; Robinson, P.H.; Ahmadi, A.; Hinders, R.; Garret, J.E. 2005. Influence of prepartum and postpartum supplementation of a yeast culture and monensin, or both, on ruminal fermentation and performance of multiparous dairy cattle. Animal Feed Science and Technology 122: 219-239.

Guedes, C.M.; Gonçalves, D.; Rodrigues, M.A.M.; Dias-Da-Silva, A. 2008. Effects of a Saccharomyces cerevisiae yeast on ruminal fermentation and fiber degradation of maize silages in cows. Animal Feed Science and Technology 145: 27-40.

Harrison, G.A.; Hemken, R.W.; Dawson, K.A.; Harmon, R.J. 1988. Influence of addition of yeast culture supplement to diets of lactating cows on ruminal fermentation and microbial populations. Journal of Dairy Science 71: 2967-2975.

Longuski, R.A.; Ying, Y.; Allen, M.S. 2009. Yeast culture supplementation prevented milk fat depression by a short term dietary challenge with fermentable starch. Journal of Dairy Science 92: 160-167.

Lund, A. 1974. Yeast and moulds in the bovine rumen. Journal of General Microbiology 81: 453-462.

Marden, J.P.; Julien, C.; Monteils, V.; Auclair, E.; Moncoulon, R.; Bayourthe, C. 2008. How does live yeast differ from sodium bicarbonate to stabilize ruminal $\mathrm{pH}$ in high-yielding dairy cows? Journal of Dairy Science 91: 3528-3535.

Michalet-Doreau, B.; Morand, D.; Martin, C. 1997. Effect of the microbial additive Levucell SC CNCM I-1077 on microbial activity in the rumen during stepwise adaptation of sheep to high concentrate diet. Reproduction, Nutrition and Development 88: $82-85$. 
Miron, J.; Yosef, E.; Ben-Ghedalia, D. 2001. Composition and in vitro digestibility of monosaccharide constituents of selected byproduct feeds. Journal of Agricultural Food Chemical 49: 23222326.

Mosoni, P.; Chaucheyras-Durand, F.; Bera-Maillet, C.; Forano, E. 2007. Quantification by real-time PCR of cellulolytic bacteria in the rumen of sheep after supplementation of a forage diet with readily fermentable carbohydrates: effect of a yeast additive. Journal of Applied Microbiology 103: 2676-2685.

National Research Council [NRC]. 2001. Nutrient Requirements of Dairy Cattle. 7ed. National Academy Press, Washington, DC, USA.

Newbold, C.J.; Wallace, R.J.; Chen, X.B.; Mcintosh, F.M. 1995. Different strains of Saccharomyces cerevisiae differ in their effects on ruminal bacterial numbers in vitro and in sheep. Journal of Animal Science 73: $1811-1818$

Newbold, C.J.; Wallace, R.J.; Mcintosh, F.M. 1996. Mode of action of the yeast Saccharomyces cerevisiae as a feed additive for ruminants. British Journal of Nutrition 76: 249-261.

Nisbet, D.J.; Martin, S.A. 1991. Effect of a Saccharomyces cerevisiae culture on lactate utilization by the ruminal bacterium Selenomonas ruminantium. Journal of Dairy Science 69: 4628-4633.

Piva, G.; Belladona, S.; Fusconi, G.; Sicbaldi, F. 1993. Effects of yeast on dairy cows performance, ruminal fermentation, blood components, and milk manufacturing properties. Journal of Dairy Science 7: 2717-2722.

Putnam, D.E.; Schwab, C.G.; Socha, M.T.; Whitehouse, N.L.; Kierstead, N.A.; Garthwaite, B.D. 1997. Effect of yeast culture in the diets of early lactation dairy cows on ruminal fermentation and passage of nitrogen fractions and amino acids to the small intestine. Journal of Dairy Science 80: 374-384.

Rosenberger, G. 1993. Clinical Examination of Cattle. 3ed. Guanabara Koogan, Rio de Janeiro, RJ, Brazil. (in Portuguese).

Salvador, S.C.; Pereira, M.N.; Santos, J.F.; Melo, L.Q.; Chaves, M.L. 2008a. Response of lactating cows to the total replacement of corn by citrus pulp and to the supplementation of organic trace minerals I. Intake and digestion. Arquivo Brasileiro de Medicina Veterinária e Zootecnia 60: 682-690. (in Portuguese, with abstract in English).

Salvador, S.C.; Pereira, M.N.; Santos, J.F.; Melo, L.Q.; Chaves, M.L. 2008b. Response of lactating cows to the total replacement of corn by citrus pulp and to the supplementation of organic trace minerals II. Performance and savings. Arquivo Brasileiro de Medicina Veterinária e Zootecnia 60: 1142-1149. (in Portuguese, with abstract in English).

SAS Institute. 1998. SAS User's Guide: Statistics. SAS Institute, Cary, NC, USA.

Schelling, G.T. 1984. Monensin mode of action in the rumen. Journal of Animal Science 58: 1518-1527.
Schingoethe, D.J.; Linke, K.N.; Kalscheur, K.F.; Hippen, A.R.; Rennich, D.R.; Yoon, I. 2004. Feed efficiency of mid-lactation dairy cows fed yeast culture during summer. Journal of Dairy Science 87: 4178-4181.

Sniffen, C.J.; Chaucheyras-Durand, F.; Ondarza, M.B.; Donaldson, G. 2007. Predicting the impact of a live yeast strain on rumen kinetics and ration formulation. p. 53-59. In: Proceedings of the South West Nutrition and Management Conference, Phoenix, AZ, USA. Available at: http://cals-cf.calsnet.arizona.edu/animsci/ansci/ swnmc/papers/2004/4-sniffen.pdf. [Accessed Aug. 10, 2009].

Theurer, C.B.; Huber, J.T.; Elorduy, A.D.; Wanderley, R. 1999. Invited review: summary of steam-flaking corn or sorghum grain for lactating dairy cows. Journal of Dairy Science 82: 1950-1959.

Wallace, R.J. 1994. Ruminal microbiology, biotechnology, and ruminant nutrition: progress and problems. Journal of Animal Science 72: 2992-3003.

Wallace, R.J.; Newbold, C.J. 2007. Microbial feed additives for ruminants. Available at: http://www.oldherbornuniversity de/ literature/books/OHUuni_book_8_article_9.pdf [Accessed Nov. 18, 2007].

Warner, A.C. 1962. Enumeration of rumen microorganisms. Journal of General Microbiology 28: 119-128.

Wiedmeier, R.D.; Arambel, M.J.; Walters, J.L. 1987. Effect of yeast culture and Aspergillus oryzae fermentation extract on ruminal characteristics and nutrient digestibility. Journal of Dairy Science 70: 2063-2068.

Wildman, E.E.; Jones, G.M.; Wagner, P.E.; Boman, R.L.; Troutt Jr., H.F.; Lesch, T.N.A. 1982. A dairy cow body condition scoring system and its relationship to selected production characteristics. Journal of Dairy Science 65: 495-501.

Williams, P.E.V.; Tait, C.A.G.; Innes, G.M.; Newbold, C.J. 1991. Effects of the inclusion of yeast culture (Saccharomyces cerevisiae plus growth medium) in the diet of dairy cows on milk yield and forage degradation and fermentation patterns in the rumen of steers. Journal of Animal Science 69: 3016-3026.

Wohlt, J.E.; Corcione, T.T.; Zajac, P.K. 1998. Effect of yeast on feed intake and performance of cows fed diets based on corn silage during early lactation. Journal of Dairy Science 81: 1345-1352.

Wohlt, J.E.; Finkelstein, A.D.; Chung, C.H. 1991. Yeast culture to improve intake, nutrient digestibility, and performance by dairy cattle during early lactation. Journal of Dairy Science 74:13951400 .

Received January 26, 2010

Accepted October 21, 2010 